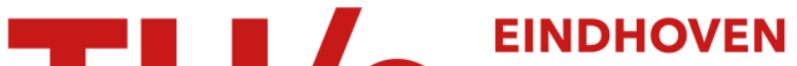 UNIVERSITY OF TECHNOLOGY
}

\section{Constitutive model for Aluminum alloys exposed to fire conditions}

\section{Citation for published version (APA):}

Maljaars, J., Soetens, F., \& Katgerman, L. (2008). Constitutive model for Aluminum alloys exposed to fire conditions. Metallurgical and Materials Transactions A: Physical Metallurgy and Materials Science, 39A(april 2008), 778-789. https://doi.org/10.1007/s11661-008-9470-0

DOI:

10.1007/s11661-008-9470-0

Document status and date:

Published: 01/01/2008

\section{Document Version:}

Publisher's PDF, also known as Version of Record (includes final page, issue and volume numbers)

\section{Please check the document version of this publication:}

- A submitted manuscript is the version of the article upon submission and before peer-review. There can be important differences between the submitted version and the official published version of record. People interested in the research are advised to contact the author for the final version of the publication, or visit the $\mathrm{DOI}$ to the publisher's website.

- The final author version and the galley proof are versions of the publication after peer review.

- The final published version features the final layout of the paper including the volume, issue and page numbers.

Link to publication

\section{General rights}

Copyright and moral rights for the publications made accessible in the public portal are retained by the authors and/or other copyright owners and it is a condition of accessing publications that users recognise and abide by the legal requirements associated with these rights.

- Users may download and print one copy of any publication from the public portal for the purpose of private study or research.

- You may not further distribute the material or use it for any profit-making activity or commercial gain

- You may freely distribute the URL identifying the publication in the public portal.

If the publication is distributed under the terms of Article 25fa of the Dutch Copyright Act, indicated by the "Taverne" license above, please follow below link for the End User Agreement:

www.tue.nl/taverne

Take down policy

If you believe that this document breaches copyright please contact us at:

openaccess@tue.nl

providing details and we will investigate your claim. 


\title{
Constitutive Model for Aluminum Alloys Exposed to Fire Conditions
}

\author{
J. MALJAARS, F. SOETENS, and L. KATGERMAN
}

An existing constitutive model for creep, developed by Dorn and Harmathy, is modified in order to be used for fire-exposed aluminum alloys. Two alloys, 5083-O/H111 and 6060-T66, are selected for the development of this constitutive model because of their different behavior at elevated temperature and their frequent application in structures for which fire design is relevant. The material parameters in the model are calibrated with the experimental results of creep tests, carried out with constant load and temperature in time. The model is validated with socalled transient state tests, with a constant load in time (stresses ranging from 20 to $150 \mathrm{~N} / \mathrm{mm}^{2}$ ) and with an increasing temperature (with heating rates ranging from $1.6^{\circ} \mathrm{C} / \mathrm{min}$ to $11^{\circ} \mathrm{C} / \mathrm{min}$ and critical temperatures ranging from $170{ }^{\circ} \mathrm{C}$ to $380^{\circ} \mathrm{C}$ ). These tests are considered as representative for fire-exposed, insulated aluminum members. The existing constitutive model of Dorn and Harmathy provides good agreement with the transient state tests carried out for the $5 \mathrm{xxx}$ series alloy, but appeared to be not suited for the $6 \mathrm{xxx}$ series alloy. This is attributed to the early development of tertiary creep in case of 6xxx series alloys. The existing model was modified to incorporate this first stage of tertiary creep, to arrive at a good agreement between the tests and the modified model for 6xxx series alloys.

DOI: $10.1007 / \mathrm{s} 11661-008-9470-0$

(C) The Minerals, Metals \& Materials Society and ASM International 2008

\section{INTRODUCTION}

Aluminum alloys in series 5xxx and 6xxx are applied in structures such as living quarters and helicopter decks on drill platforms, fast ferries, and yachts. In case a fire breaks out in such a structure, people have to be able to safely escape before the structure collapses. National laws and regulations apply on the time that the structure has to keep its load-bearing function before it collapses. This time is called the fire resistance. Typical fire resistances specified are 30,60, 90, or 120 minutes. Because of their relatively low melting temperature, low density, and high thermal conductivity, load-bearing structures composed of aluminum alloys need to be protected (insulated) in almost all cases in order to fulfill these fire resistances. ${ }^{[1]}$ In many cases, the temperature of fire-exposed insulated aluminum members increases approximately linearly with time.

To be able to determine the amount of insulation required, knowledge on the constitutive properties of the applied alloys when exposed to fire is required. The constitutive relations at elevated temperature are usually determined with one of the following types of tests.

J. MALJAARS, Researcher, is with Netherlands Institute of Metals Research, P.O. Box 5008, 2600 GA Delft, The Netherlands. J. MALJAARS and F. SOETENS, Professor, are with Architecture, Building and Planning, Eindhoven University of Technology, P.O. Box 513, 5600 MB Eindhoven, The Netherlands and Civil Infrastructure, TNO, P.O. Box 49, 2600 AA Delft, The Netherlands. Contact e-mail: johan.maljaars@tno.nl L.KATGERMAN, Professor, is with Mechanical, Maritime and Materials Engineering, Delft University of Technology, Mekelweg 2, 2628 CD Delft, The Netherlands.

Manuscript submitted July 23, 2007.

Article published onlined February 12, 2008 (a) Steady-state tests: specimens are subjected to a constant temperature and a certain strain rate. The force (stress) is measured.

(b) Transient state tests: specimens are subjected to a (linearly) increasing temperature and a certain stress in time. The strain is measured.

(c) Creep tests: specimens are subjected to a constant temperature and a constant stress in time. The strain is measured.

Based on steady-state tests, data are given on the 0.2 pct proof stress of some aluminum alloys at elevated temperature in Reference 2. These data are incorporated in the design code for fire-exposed aluminum structures Eurocode 9, Part 1-2. ${ }^{[3]}$ The Ramberg-Osgood relation is often used in engineering practice to describe the stress-strain relationship. ${ }^{[4]}$ Values for the hardening factor of the Ramberg-Osgood relation for aluminum alloys at elevated temperature are determined and used in the fire design of frames. ${ }^{[5]}$

However, the temperature and load history in steadystate test are not representative for a fire. Transient state tests are usually considered as appropriate tests for simulation of fire conditions. Due to viscoplastic behavior (or creep), overaging, and annealing, the strength resulting from steady-state tests differs in general from the strength determined in transient state tests.

The constitutive behavior of aluminum alloys at elevated temperature is dominated by creep. In the 1950s, Dorn proposed a model for secondary creep of metals. ${ }^{[6]}$ Harmathy extended Dorn's model to account for primary creep and this model has been used to simulate the deflection of fire-exposed steel beams. ${ }^{[7,8]}$ Their model is used in this article as a basis to determine 


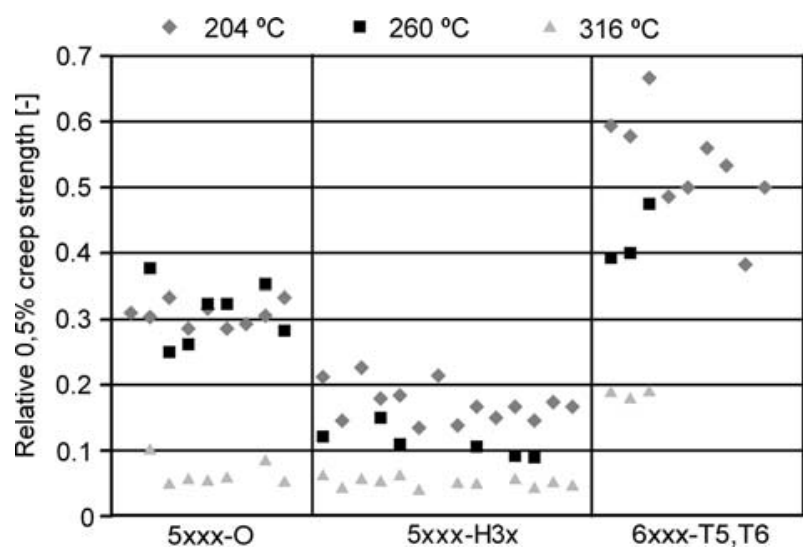

Fig. 1-Ratios between stress resulting in 0.5 pct creep strain after $60 \mathrm{~min}$ and ultimate tensile strength at room temperature. ${ }^{[9]}$

the constitutive properties of fire-exposed aluminum alloys.

Extensive data on the short-time strength and creep strength of commercial aluminum alloys are given in Reference 9. Figure 1 gives the relative creep strength (defined as the ratio between the stress resulting in 0.5 pct creep strain after 60 minutes at elevated temperature and the ultimate tensile strength at room temperature) for alloys in series $5 \mathrm{xxx}$ and $6 \mathrm{xxx}$, based on the data in Reference 9. The relative creep strength differs between the various alloy series and, to a less extent, between tempers. In this research, the constitutive properties of two alloys with different creep behavior are determined, one in series 5xxx (alloy 5083-H111) and one in series 6xxx (alloy 6060-T66).

\section{EXISTING CONSTITUTIVE MODEL FOR CREEP}

The strain as a function of time resulting from a creep test is usually divided into a primary stage with decreasing strain rate, a secondary stage with constant, minimum strain rate, and a tertiary stage with increasing strain rate until rupture occurs (Figure 2(a)).

A constitutive model exists to describe the primary and secondary stages of the creep curve, which is known as the Dorn-Harmathy creep model (Eqs. [1] and [2]):

$$
\begin{gathered}
\dot{\varepsilon}_{t, I I}=Z \cdot \mathrm{e}^{\frac{-Q}{\mathrm{R} \cdot T}} \\
\dot{\varepsilon}_{t, I+I I}=\dot{\varepsilon}_{t, I I} \cdot \operatorname{coth}^{2}\left(\frac{\varepsilon_{t, I+I I}}{\varepsilon_{t 0}}\right)
\end{gathered}
$$

Equation [1] describes Dorn's widely applied model for secondary creep, ${ }^{[6]}$ where $\dot{\varepsilon}_{t, I I}$ is the secondary strain rate. The influence of temperature is incorporated by the well-known Arrhenius equation $(\exp (-Q /(\mathrm{R} T)))$, where $Q$ is the material-dependent activation energy for creep, $\mathrm{R}$ is the universal gas constant, and $T$ is the temperature. Further, $Z$ is the Zener-Holloman parameter ${ }^{[10]}$ describing the influence of stress on the secondary strain rate. Equation [3] was proposed for this relation in Reference 11 , in which $A, \alpha$, and $n$ are material parameters.

$$
Z=A \cdot(\sinh (\alpha \cdot \sigma))^{n}
$$

Equation [2] is proposed by Harmathy ${ }^{[7]}$ for incorporation of the primary creep strain $\varepsilon_{t, I}$. This proposal is based on curve fitting of creep test results of mild steel specimens, where $\dot{\varepsilon}_{t, I+I I}$ is the strain rate of the primary and secondary creep stages. Parameter $\varepsilon_{t 0}$ is the projection back to zero time of the secondary strain curve (Figure 2(b)). Equation [4] was proposed for this parameter, in which $D$ and $m$ are material parameters. It was noted that Eq. [4] is based on a plot with badly scattered data.

$$
\varepsilon_{t 0}=D \cdot(\sigma)^{m}
$$

Harmathy ${ }^{[7]}$ also gave an explicit function of Eq. [2], which is an approximation based on the first two terms in the Taylor series. Although Eq. [2] is derived for

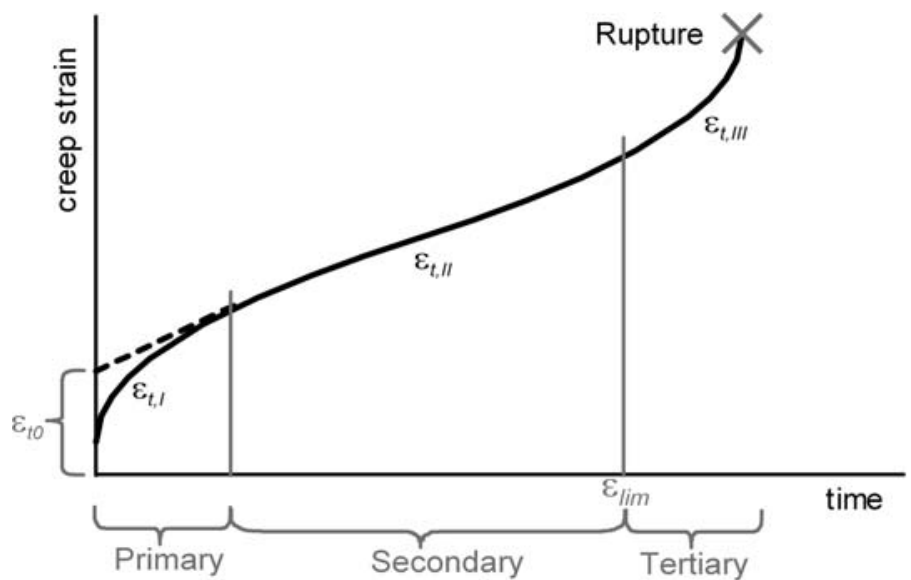

(a)

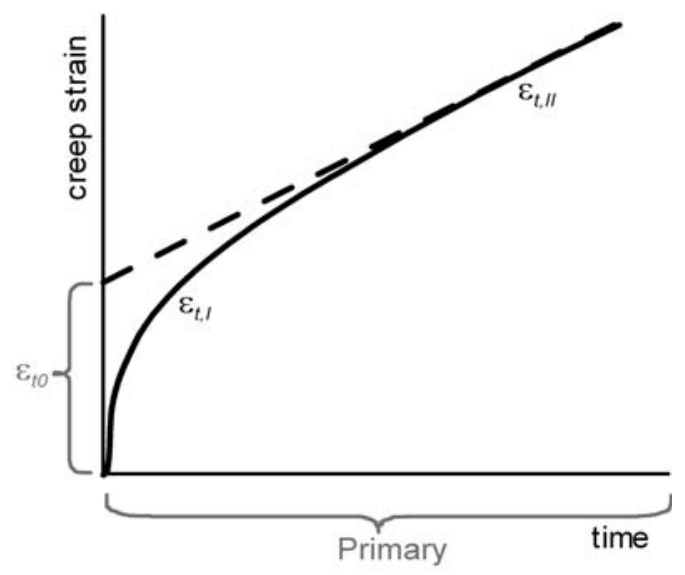

(b)

Fig. 2-Creep curves: $(a)$ entire creep curve and (b) primary creep curve. 


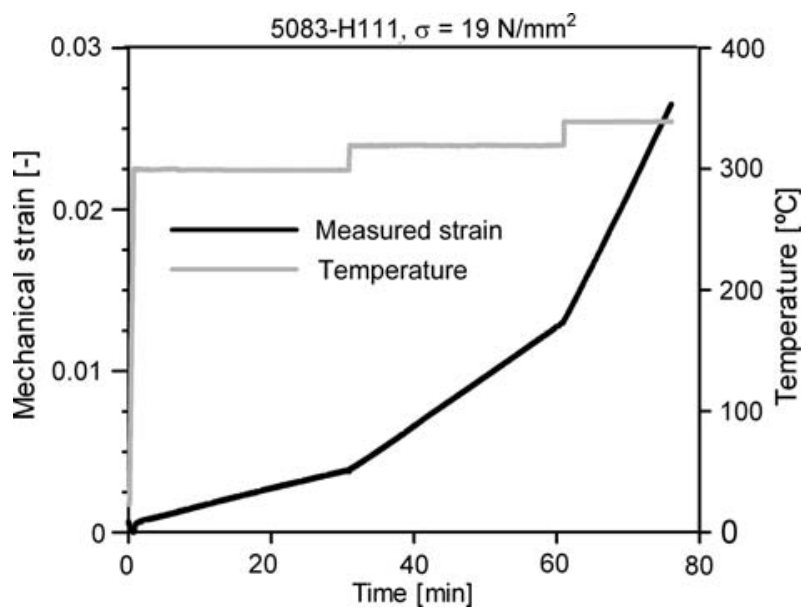

Fig. 3-Temperature and measured mechanical strain as a function of time in a creep test on alloy 5083-H111 with constant stress level $\sigma=19 \mathrm{~N} / \mathrm{mm}^{2}$

constant stress in time, it was shown that the equation can also be applied with reasonable accuracy for nonconstant stress in time, provided $d \sigma / d t$ is not too large.

Equation [1] assumes that the influences of stress and temperature on the secondary strain rate are separable. This allows for an easy determination of the parameters. The activation energy $Q$ can be determined in tests with a constant stress and a stepwise increased temperature, as shown in Figure 3 . In the same way, $Z$ can be determined in tests with a constant temperature and a stepwise increased stress.

The model extension for primary creep (Eqs. [2] and [4]) is based on creep tests on steel specimens. It is not known whether these equations are also applicable to aluminum alloys. In case of the heat treatable alloy 6060-T66, overaging and annealing may influence the strain rate. This is not incorporated in the existing constitutive equations presented in this section. In order to determine the applicability of the equations to aluminum alloys, and to determine whether these equations can be applied for a temperature increasing in time as present in fire exposure, a test program was carried out.

\section{EXPERIMENTAL SETUP AND TEST PROGRAM}

Three-point bending tests were applied for calibrating the modulus of elasticity. The material parameters in Eqs. [1] through [4] were determined from uniaxial creep tests in tension. Uniaxial transient state tensile tests were used for validation of the model.

\section{A. Creep Tests and Transient State Tests}

The creep and transient state tests were carried out in a Gleeble 3800 thermomechanical simulator (dual servo valve) installed with a pocket jaw. Deformations were measured with a hot zone extensometer attached to the sample. The temperature was measured with a thermocouple spot-welded at the middle of the specimen.

The specimens were standard flat tensile specimens with a parallel length of $75 \mathrm{~mm}$, a width of $12.5 \mathrm{~mm}$, and a thickness of $5 \mathrm{~mm}$. The specimens of alloy 5083H111 were obtained from a rolled plate, with the parallel length perpendicular to the rolling direction. The specimens of alloy 6060-T66 originated from extruded strip, with the parallel length parallel to the extrusion direction. The chemical composition is given in Table I. The elements, whose content is less than 0.05 pct, are not listed.

The material parameters for secondary creep were determined with creep tests such as shown in Figure 3, with stepwise varied loads and temperatures. The ranges of loads, temperatures, and times at which the creep tests are carried out and the number of creep tests are summarized in Tables II and III. The temperature and the load were adjusted in 5 seconds.

The creep specimens were subjected to a constant load. Only those test results were considered in which the strain developed at the end of the test was so small

Table III. Conditions in Transient State Tests

\begin{tabular}{lccc}
\hline Alloy & Stress Range & Heating Rates & $\begin{array}{c}\text { Number } \\
\text { of Tests }\end{array}$ \\
\hline $5083-\mathrm{H} 111$ & 20 to $100 \mathrm{~N} / \mathrm{mm}^{2}$ & 2.4 to $11\left({ }^{\circ} \mathrm{C} / \mathrm{min}\right)$ & 10 \\
6060 -T66 & 40 to $150 \mathrm{~N} / \mathrm{mm}^{2}$ & 1.6 to $11\left({ }^{\circ} \mathrm{C} / \mathrm{min}\right)$ & 11 \\
\hline
\end{tabular}

Table I. Chemical Composition of the Creep and Transient State Test Specimens (Weight Percent)

\begin{tabular}{lcccccccrrr}
\hline Alloy & $\mathrm{Si}$ & $\mathrm{Fe}$ & $\mathrm{Mg}$ & $\mathrm{Mn}$ & $\mathrm{Cu}$ & $\mathrm{Zn}$ & $\mathrm{Ni}$ & $\mathrm{Cr}$ & $\mathrm{Ti}$ & $\mathrm{Al}$ \\
\hline 5083-H111 & 0.1342 & 0.2783 & 4.44 & 0.4747 & 0.0485 & 0.0218 & - & 0.0748 & 0.0175 & 94.47 \\
6060-T66 & 0.4463 & 0.1649 & 0.4135 & 0.0006 & 0.0038 & 0.0055 & 0.0059 & 0.0024 & 0.003 & 98.92 \\
\hline
\end{tabular}

Table II. Conditions in Creep Tests

\begin{tabular}{lccccc}
\hline Alloy & Stress Range & Temperature Range & Total Creep Time & Duration of Each Step $^{*}$ & Number of Tests $^{\circ}$ \\
\hline $5083-\mathrm{H} 111$ & 20 to $110 \mathrm{~N} / \mathrm{mm}^{2}$ & $200{ }^{\circ} \mathrm{C}$ to $340{ }^{\circ} \mathrm{C}$ & 50 to $110(\mathrm{~min})$ & 10 to $20(\mathrm{~min})$ & 13 \\
$6060-\mathrm{T} 66$ & 30 to $150 \mathrm{~N} / \mathrm{mm}^{2}$ & $200{ }^{\circ} \mathrm{C}$ to $340{ }^{\circ} \mathrm{C}$ & 20 to $30(\mathrm{~min})$ & $10(\mathrm{~min})$ & 33 \\
\hline
\end{tabular}

*Period during which load and temperature are kept constant. 
that the engineering stress was almost equal to the true stress. The tests could therefore be regarded as tests with an (almost) constant stress in time.

In section 1, it was mentioned that the temperature of insulated members increases approximately linear from room temperature to collapse in 30 up to 120 minutes. This means that the period with a high temperature (near failure) is relatively short. For alloy 6060-T66, the period at elevated temperature may influence the temper. Therefore, the creep tests are carried out with relatively short creep times. In order to determine the influence of the thermal exposure period on alloy 6060T66, a limited number of additional creep tests were carried out, which were first subjected to an elevated temperature without being loaded. After this period, the actual creep test was carried out by applying the mechanical load. Two types of these tests were conducted, at temperatures of $180{ }^{\circ} \mathrm{C}, 220^{\circ} \mathrm{C}, 250^{\circ} \mathrm{C}$, and $300{ }^{\circ} \mathrm{C}$ :

(1) tests with a constant elevated temperature during 90 minutes prior to loading; and

(2) tests with an increasing temperature, from room to test temperature, in 90 minutes prior to loading.

The ranges of loads and heating rates applied in the transient state tests and the number of tests are summarized in Table III. The heating rates applied were such that rupture occurred after 30 to 120 minutes.

\section{B. Three-Point Bending Tests}

The modulus of elasticity was determined from tests on aluminum strips loaded in bending. The three-point bending tests were carried out in a conventional electrical furnace. One edge of the strip was supported by a roll, whereas the other edge was supported by a hinge. The strips had a span of $250 \mathrm{~mm}$, a width of $30 \mathrm{~mm}$, and a thickness of $5 \mathrm{~mm}$ for alloy 5083-H111 and $2 \mathrm{~mm}$ for alloy 6060-T66. The specimens used in these tests originated from other batches than used for the creep and transient state tests, but the chemical composition was almost equal.

The specimens were subjected to a constant temperature and a stepwise varying force at midspan. The linear variable differential transformers (LVDTs) outside the furnace were used to measure the deformations at midspan and at the supports. Invarsteel pins were applied between the LVDTs and the specimen. The measurements at the supports were used to correct for elastic deformation of the supports. The temperature was determined with four thermocouples spot-welded to the specimen. Figure 4 gives an overview of the test setup as well as one of the loaded strips.

\section{EXPERIMENTAL RESULTS OF CREEP TESTS}

\section{A. Secondary Creep Results}

Figure 5 shows the secondary strain rate as a function of the reciprocal of the temperature of the creep tests with a constant load and a stepwise varied temperature.

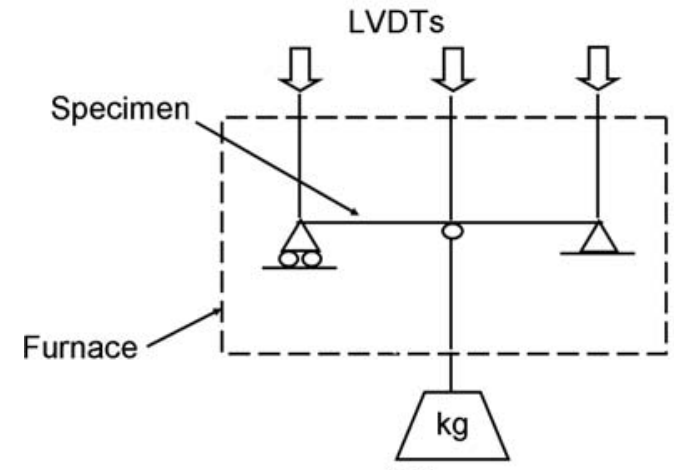

(a)

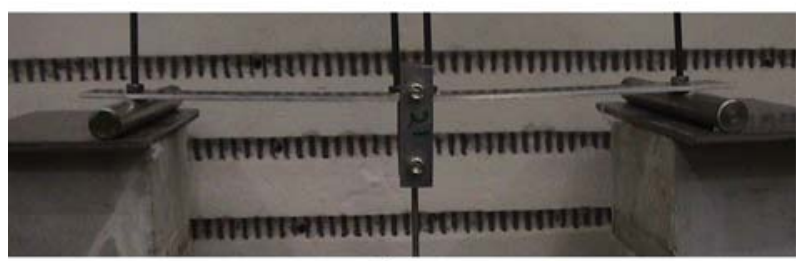

(b)

Fig. 4-Test setup for the three-point bending tests and a loaded strip in bending.

The values for the activation energy are determined based on the slopes of the curves, and are $1.52 \cdot 10^{5} \mathrm{~J} / \mathrm{mol}$ and $1.95 \cdot 10^{5} \mathrm{~J} / \mathrm{mol}$ for alloys 5083-H111 and 6060-T66, respectively (for stress ranges of 20 to $110 \mathrm{~N} / \mathrm{mm}^{2}$ and 30 to $150 \mathrm{~N} / \mathrm{mm}^{2}$, respectively).

Using Dorn's Eq. [1] and the values determined for the activation energy, the Zener-Holloman parameter $Z$ was determined for each creep test. Figure 6 gives $Z$ (on logarithmic scale) as a function of the stress. Equations [5] and [6] are proposed for alloys 5083H111 and 6060-T66, with $Z$ in (/min)

$$
\begin{aligned}
& Z=6.7 \cdot 10^{10} \cdot(\sinh (0.025 \cdot \sigma))^{3} \\
& \quad \text { for } 20 \mathrm{~N} / \mathrm{mm}^{2} \leq \sigma \leq 110 \mathrm{~N} / \mathrm{mm}^{2} \\
& \quad(\text { alloy } 5083-\mathrm{H} 111) \\
& Z=7.0 \cdot 10^{12} \cdot(\sinh (0.04 \cdot \sigma))^{3} \\
& \quad \text { for } 30 \mathrm{~N} / \mathrm{mm}^{2} \leq \sigma \leq 150 \mathrm{~N} / \mathrm{mm}^{2} \\
& \quad(\text { alloy } 6060-\mathrm{T} 66)
\end{aligned}
$$

\section{B. Influence of Thermal Exposure Period}

The preceding results are obtained from the creep tests heated and loaded directly (i.e., tests of Table II). This section gives the results of the tests that are subjected to an elevated temperature for 90 minutes prior to loading.

For temperatures lower than approximately $240{ }^{\circ} \mathrm{C}$, the secondary strain rates determined in these tests were almost equal to those obtained in the tests loaded directly. For higher temperatures, the tests subjected to a constant elevated temperature prior to loading showed 

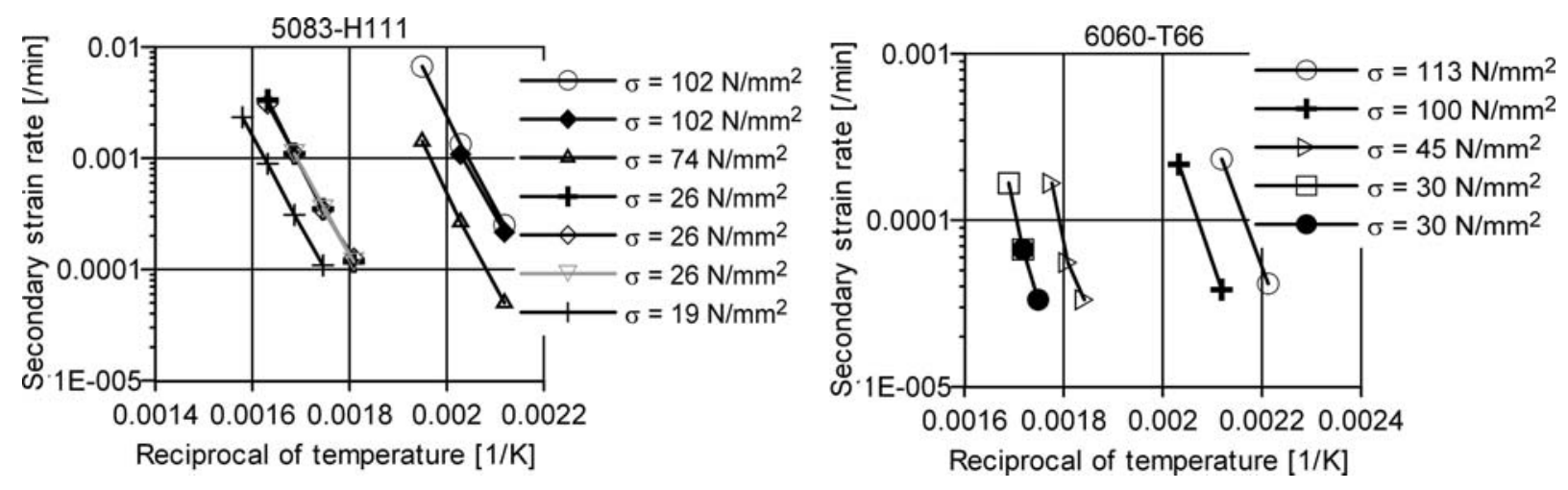

Fig. 5-Secondary strain rate as a function of reciprocal of the temperature.
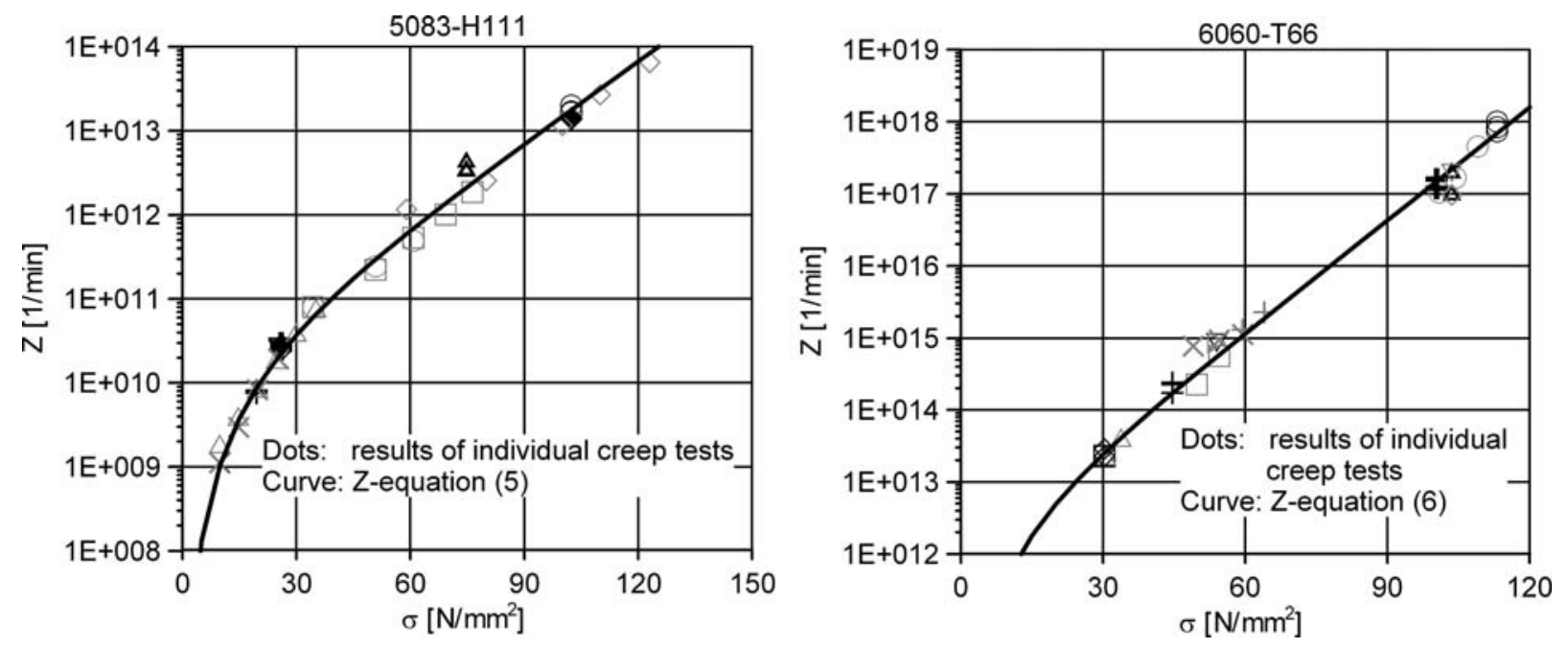

Fig. 6-Relation between $\log Z$ and $\sigma$.

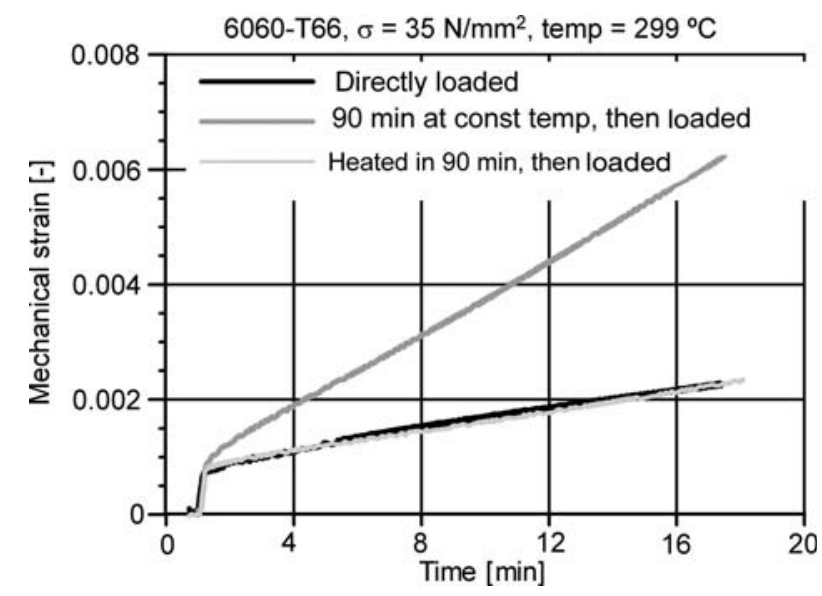

Fig. 7- Strain as a function of time of creep tests on alloy 6060-T66, with stress $\sigma=35 \mathrm{~N} / \mathrm{mm}^{2}$ and temperature $=299^{\circ} \mathrm{C}$.

higher strain rates than the tests loaded directly, while the strain rates of the tests with an increasing temperature were approximately equal to the tests loaded directly. Figure 7 gives an example.

\section{Primary Creep Results}

Due to slip between the specimen and the clamps of the extensometer at the start of loading, the projection back to zero time of the secondary strain curve could not be accurately determined in case of alloy 5083-H111. Instead, data of $\varepsilon_{t 0}$ given in Reference 12 on alloy 5083$\mathrm{O}$ were used. Before carrying out the tests on alloy $6060-$ T66, stronger springs were applied at the clamps of the extensometer so that slip did not occur. The values for $\varepsilon_{t 0}$ could be determined with sufficient accuracy for alloy 6060-T66. The individual test data are given with dots in Figure 8. The gray lines in the graphs represent Eqs. [7] and [8] for alloys 5083-H111 and 6060-T66, respectively.

$$
\begin{aligned}
& \varepsilon_{t 0}=4 \cdot 10^{-10} \cdot(\sigma)^{3.4} \quad(\text { alloy } 5083-\mathrm{H} 111) \\
& \varepsilon_{t 0}=2 \cdot 10^{-18} \cdot(\sigma)^{7.45} \quad(\text { alloy } 6060-\mathrm{T} 66)
\end{aligned}
$$

\section{Tertiary Creep}

In the case of alloy 6060-T66, the tertiary creep stage with increasing strain rate started after a relatively short 


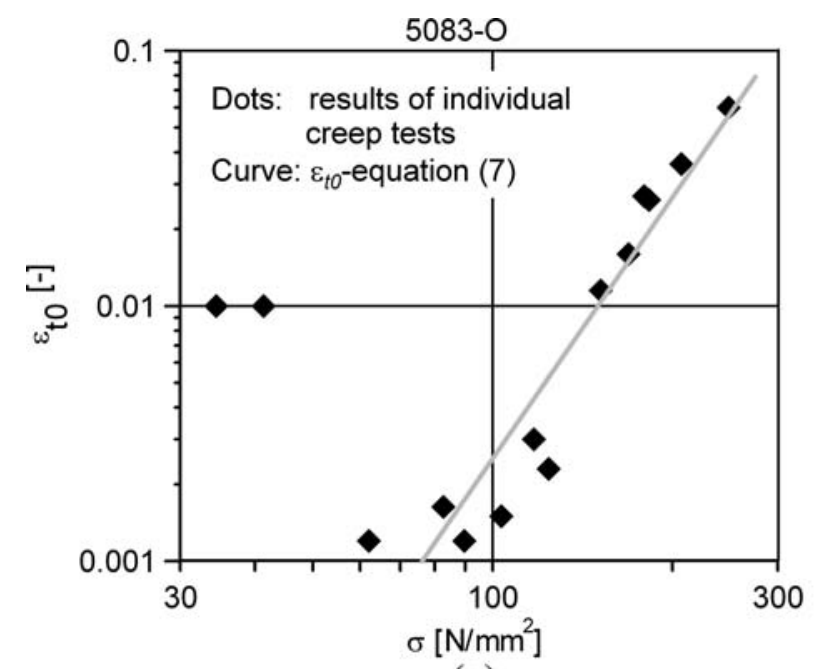

(a)

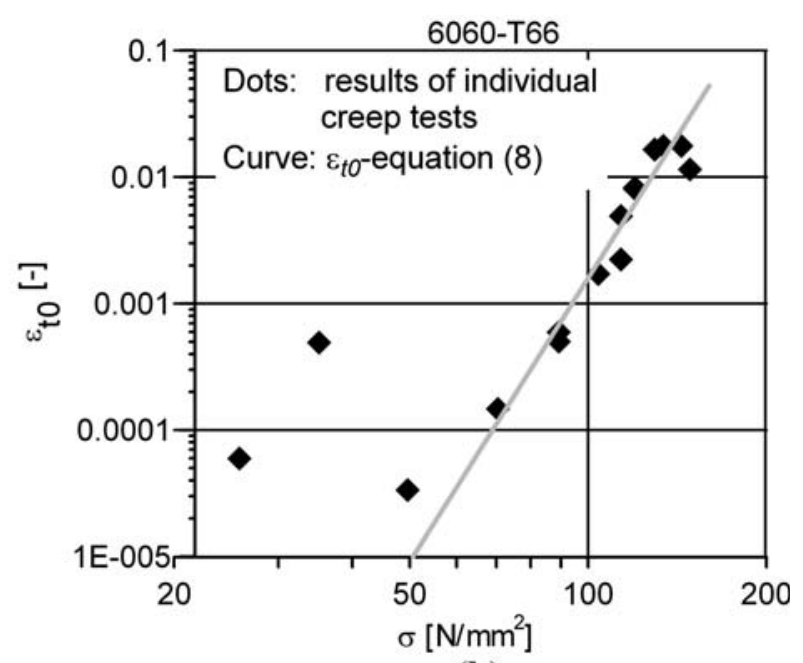

(b)

Fig. 8-Primary creep parameter $\varepsilon_{t 0}$ : $(a)$ data on alloy 5083-O according to Ref. 12 and $(b)$ data on alloy 6060-T66 determined in current creep tests.

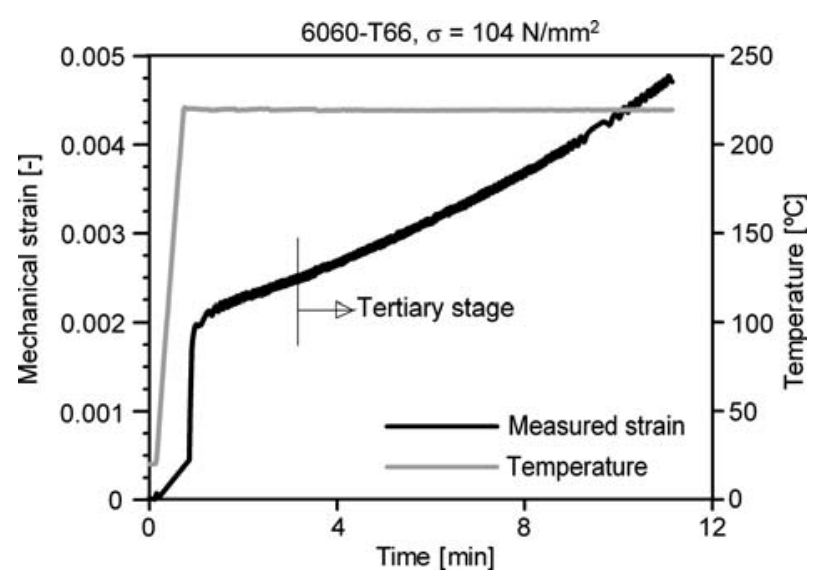

Fig. 9- Strain as a function of time in a creep test on alloy 6060T66 with $\sigma=104 \mathrm{~N} / \mathrm{mm}^{2}$ and a temperature of $220{ }^{\circ} \mathrm{C}$. period and a small creep strain. In some cases, the secondary stage even seemed to be absent (Figure 9). Evaluating all creep tests, a clear correlation between the load and temperature conditions and the duration of the secondary stage was not found. Instead, it appeared that the tertiary stage started at a plastic strain of approximately $2.5 \cdot 10^{-3}$, independent of the load or temperature condition.

Investigating the tertiary creep stage of the creep tests on alloy 6060-T66, it appeared that a linear relation exists between the creep-strain rate and the creep strain for the tertiary creep stage (Figure 10). This relation was present in all tests at all temperatures and stress levels investigated. Some tests were repeated with different gage lengths of the extensometer, ranging from 14 to $31 \mathrm{~mm}$. The creep development in time in the tertiary stage appeared to be independent of this gage length of the LVDT, up to a strain of approximately $2 \cdot 10^{-2}$. The linear relation between the strain and the strain rate was
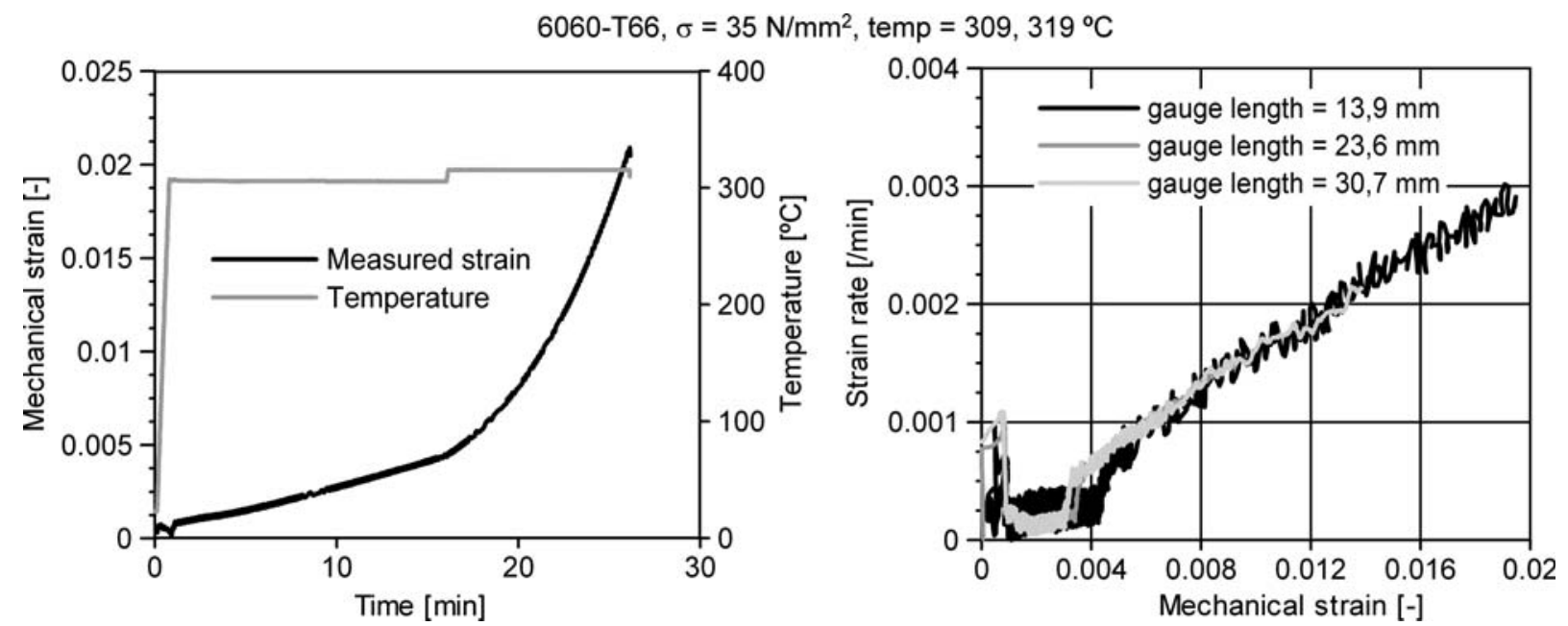

Fig. 10 - Creep tests on alloy 6060-T66 (a) strain as a function of time and (b) strain rate as a function of strain. 
equal for all gage lengths (Figure 10). Measurements on the thickness and width of the specimens loaded up to this strain (0.02) did not reveal a clear necking location.

\section{EXPERIMENTAL RESULTS OF TRANSIENT STATE TESTS}

Figures 11 and 12 show some results of transient state tests with a constant heating rate and a constant stress on alloy 5083-H111 and alloy 6060-T66, respectively. The test results are indicated with black curves (gray curves are introduced later in this article). The curves in Figures 11 and 12 show a small strain increase up to approximately $50{ }^{\circ} \mathrm{C}$ before failure. This is followed by an exponential increase of the strain and the strain rate.
In agreement with custom practice for fire design, the critical temperature (i.e., failure temperature) in this article is defined as the vertical asymptote of the strain $v s$ temperature curve (Figure 13). Figure 14 gives the critical temperatures of all transient state tests. Distinction is made in the figure between low heating rates (ranging from $1.5^{\circ} \mathrm{C} / \mathrm{min}$ to $2.6^{\circ} \mathrm{C} / \mathrm{min}$ ) and high heating rates (ranging from $6^{\circ} \mathrm{C} / \mathrm{min}$ to $11^{\circ} \mathrm{C} / \mathrm{min}$ ). Figure 14 shows that the critical temperature of the tests with a low heating rate is lower than that of tests with a high heating rate.

\section{EXPERIMENTAL RESULTS OF THE THREE-POINT BENDING TESTS}

The modulus of elasticity was evaluated from the threepoint bending tests as well as the steady-state tensile tests
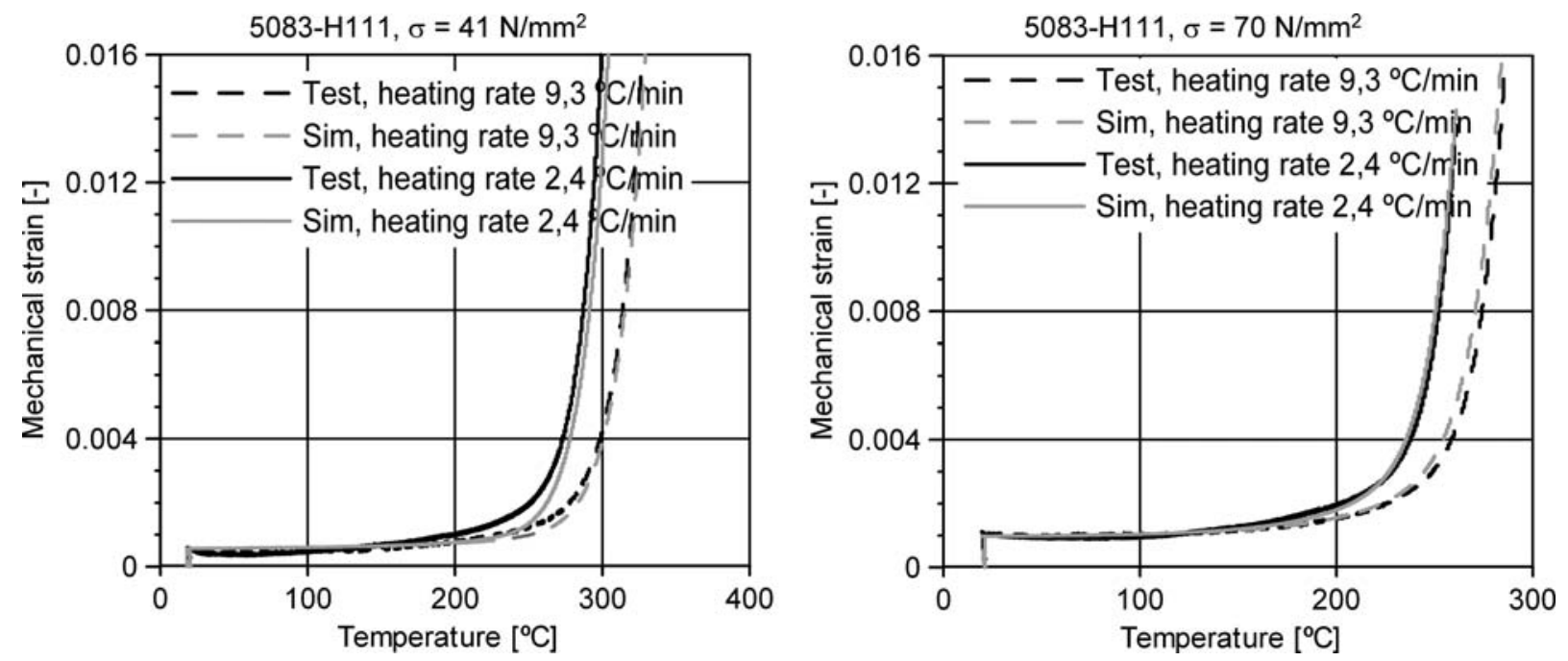

Fig. 11-Strain as a function of temperature of transient state tests and simulations on alloy 5083-H111: (a) constant stress of $41 \mathrm{~N} / \mathrm{mm}^{2}$ and $(b)$ constant stress of $70 \mathrm{~N} / \mathrm{mm}^{2}$.
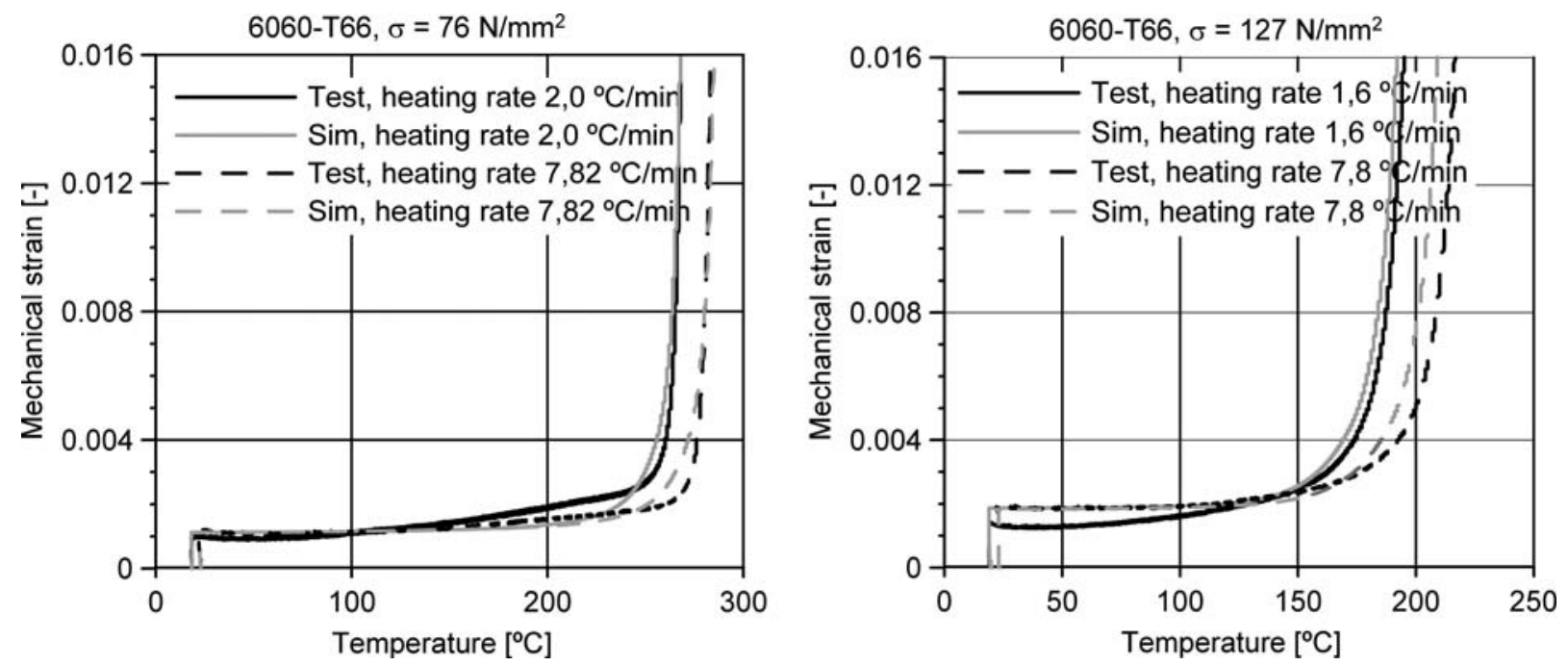

Fig. 12 - Strain as a function of temperature of transient state tests and simulations on alloy 6060-T66: $(a)$ constant stress of $76 \mathrm{~N} / \mathrm{mm}^{2}$ and $(b)$ constant stress of $127 \mathrm{~N} / \mathrm{mm}^{2}$. 


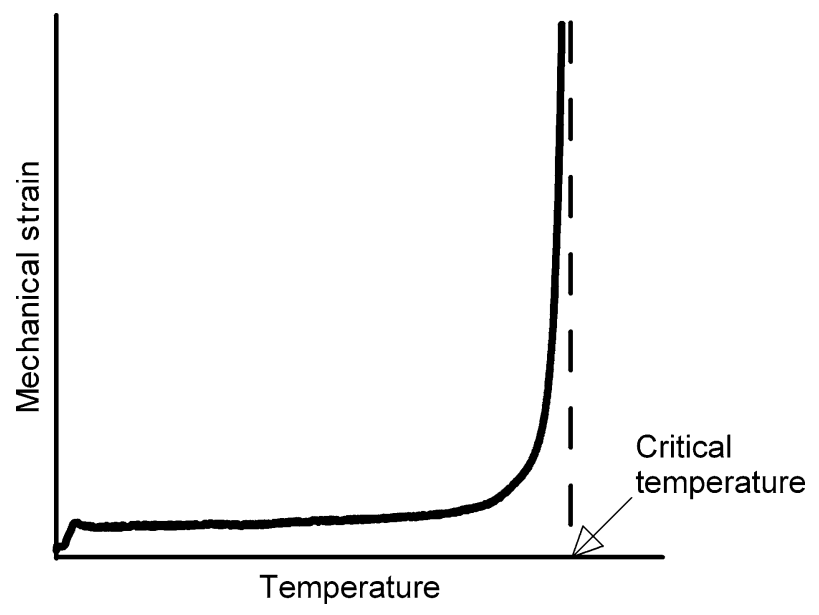

Fig. 13-Definition of the critical temperature.

in Reference 9. The tests in Reference 9 are carried out on alloys with a similar chemical composition.*

*Ref. 9 does not give properties on alloy 6060. Therefore, the modulus of elasticity was compared with alloy 6063 , which has a comparable chemical composition.

Figure 15 gives a comparison of the results of these two types of tests. The following empirical relations were determined for the modulus of elasticity as a function of the temperature:

$$
\begin{aligned}
& \text { Alloy } 5083-\mathrm{H} 111: \quad E=72,000-10 \cdot \theta-0,21 \cdot \theta^{2} \\
& \quad \text { for } 20^{\circ} \mathrm{C} \leq \theta \leq 350^{\circ} \mathrm{C}
\end{aligned}
$$

$$
\begin{aligned}
& \text { Alloy } 6060 \text {-T } 66: \quad E=68,000-10 \cdot \theta-0,21 \cdot \theta^{2} \\
& \text { for } 20^{\circ} \mathrm{C} \leq \theta \leq 350{ }^{\circ} \mathrm{C}
\end{aligned}
$$

where $\theta$ is the aluminum temperature in degrees Celsius. These equations are indicated with curves in Figure 15. The fact that the modulus of elasticity in compression is approximately 2 pct higher than that in tension ${ }^{[9]}$ is neglected in the evaluation.

\section{DISCUSSION OF TEST RESULTS}

The modulus of elasticity based on bending tests on alloys 5083 and 6060 agrees reasonably with values on alloys 5083 and 6063 given in Reference 9. Only for high temperatures $\left(>300{ }^{\circ} \mathrm{C}\right)$, the modulus of elasticity in Reference 9 was lower than that of the bending tests. This is attributed to the large influence of creep at these temperatures, so that plastic strain already evolves at very low stress levels.

The secondary creep parameters in Figures 5 and 6 were consistent with the relations according to Eqs. [1] through [4]. Table IV gives an overview of all materialdependent parameters determined in the creep tests and which have to be applied in Eqs. [1] through [4].

The value for $Q$ was equal for the entire stress range investigated, indicating that one creep process is dominant in this entire stress range. The values for $Q$ were similar to values found in literature on other alloys in series $5 \mathrm{xxx}$ and $6 \mathrm{xxx}$ (Table V).

The scatter in the relation between $(\log \sigma)$ and $\left(\log \varepsilon_{t 0}\right)$ (Figure 8) is relatively large. Especially in the case of small stress levels and corresponding small values for $\varepsilon_{t}$, the results deviate from the lines proposed with Eqs. [7] and [8], which is attributed to errors in measuring such small strains. On the other hand, the exact value for $\varepsilon_{t 0}$ is not important if it is so small. Use of Eq. [2] resulted in a slightly slower strain development in the primary creep stage compared to the creep tests.

Figure 7 shows that the strain rate in tests on alloy 6060-T66 depends on the thermal exposure period. This is attributed to overaging or annealing. However, in tests with heating conditions as present in fire exposure (increasing temperature), the strain rate was equal to that of the test with direct loading. It is concluded that although overaging and annealing influence the constitutive behavior of alloy 6060-T66, it is not necessary to explicitly take this into account if the constitutive model is used for fire conditions. The difference in strain
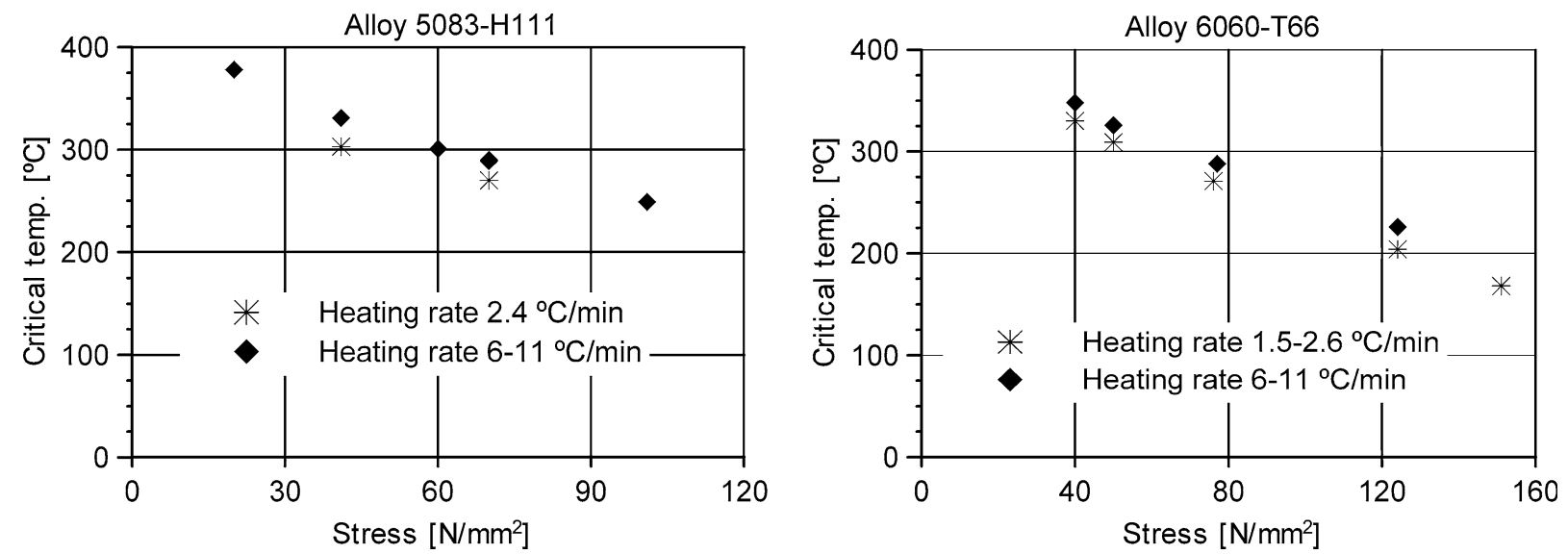

Fig. 14 Critical temperatures of the transient state tests: (a) alloy 5083-H111 and (b) alloy 6060-T66. 

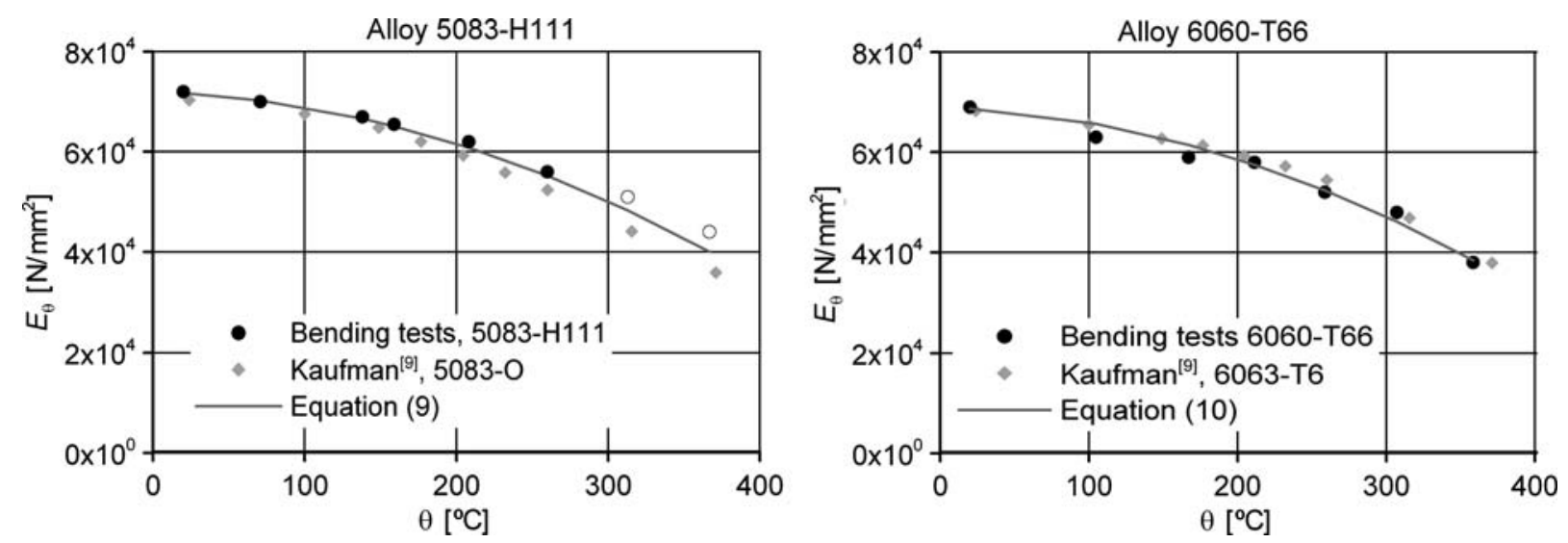

Fig. 15-Modulus of elasticity as a function of the temperature.

Table IV. Material Parameters in Equations [1] through [4], [9], and [10]

\begin{tabular}{llll}
\hline Parameter & \multicolumn{1}{c}{ Alloy 5083-H111 } & \multicolumn{1}{c}{ Alloy 6060-T66 } & \multicolumn{1}{c}{ Application Range } \\
\hline$Q$ & $1.52 \cdot 10^{5}(\mathrm{~J} / \mathrm{mol})$ & $1.95 \cdot 10^{5}(\mathrm{~J} / \mathrm{mol})$ & $\sigma=20$ to $110 \mathrm{~N} / \mathrm{mm}^{2}$ \\
$A$ & $6.7 \cdot 10^{10}(/ \mathrm{min})$ & $7.0 \cdot 10^{12}(/ \mathrm{min})$ & $($ alloy $5083-\mathrm{H} 111)$ \\
$\alpha$ & $2.5 \cdot 10^{-2}$ & $4.0 \cdot 10^{-2}$ & $\sigma=30$ to $150 \mathrm{~N} / \mathrm{mm}^{2}$ \\
$n$ & 3.0 & 3.0 & $($ alloy $6060-\mathrm{T} 66)$ \\
$D$ & $4.0 \cdot 10^{-10}$ & $2.0 \cdot 10^{-18}$ & - \\
$m$ & 3.40 & 7.45 & $\theta=20^{\circ} \mathrm{C}$ to $350{ }^{\circ} \mathrm{C}$ \\
\hline -modulus & $71,000-10 \theta-0.21 \theta^{2}\left(\mathrm{~N} / \mathrm{mm}^{2}\right)$ & $69,000-10 \theta-0.21 \theta^{2}\left(\mathrm{~N} / \mathrm{mm}^{2}\right)$ & $\theta$ \\
\hline
\end{tabular}

${ }^{*} \theta=$ temperature in ${ }^{\circ} \mathrm{C}$.

Table V. Activation Energy for Creep of a Number of Aluminum Alloys (Selection of Literature Data)

\begin{tabular}{lll}
\hline & $\begin{array}{c}\text { Activation Energy } \\
(Q)(\mathrm{kJ} / \mathrm{mol})\end{array}$ & \multicolumn{1}{c}{ Reference } \\
\hline Alloy & \multicolumn{1}{c}{ current test series } \\
\hline Alloy 5083-H111 & 151 & 6 \\
Alloy with 1.6 pct Mg & 13 \\
Alloy 5070A & 153 & 14 \\
Alloy 5083 & $170\left(\right.$ at $\left.300{ }^{\circ} \mathrm{C}\right)$ & 15 \\
Alloy 5182 & 174 & 16 \\
Alloy 5182 & 192 & 17 \\
Alloy 5182 & 125 & current test series \\
Alloy 6060-T66 & $\mathbf{1 9 5}$ & 14 \\
Alloy 6082 & 231 (at $\left.300{ }^{\circ} \mathrm{C}\right)$ & 18 \\
Alloy 6092 & 135 & \\
\hline
\end{tabular}

development in the transient state tests (Figures 11, 12, and 14) for different heating rates, therefore, is entirely attributed to the influence of creep.

When it is recognized that the total mechanical strain $\varepsilon$ at time $t$ is equal to the summation of the elastic strain and the creep-strain rate integrated in time (Eq. [11]), the constitutive model can be applied to simulate the transient state tests:

$$
\varepsilon=\frac{\sigma}{E}+\int_{0}^{t} \dot{\varepsilon}_{t, I+I I} d t
$$

where $\varepsilon=$ the total strain, $E=$ modulus of elasticity, and $\dot{\varepsilon}_{t, I+I I}$ is the creep-strain rate according to Eqs. [1] through [4]. The reversible part of the creep strain of metals is usually negligible compared to the irreversible part. ${ }^{[19]}$ In the constitutive model applied in this research, the total creep strain is assumed to be irreversible.

Strictly, Eqs. [1] and [2] are applicable only for temperatures higher than 0.5 times the absolute melting temperature, which is approximately $150{ }^{\circ} \mathrm{C}$ for most $5 \times x x$ and $6 x x x$ alloys. However, for simulation of the transient state tests the constitutive model has to be used also for temperatures between ambient temperature and $150{ }^{\circ} \mathrm{C}$. This is justified because the creep strain developed at such low temperatures is negligible for the stress levels relevant for fire design (Figures 11, 12, and 14). Consequently, the possible error introduced by using Eqs. [1] and [2] for the entire temperature range is negligible.

Equation [11] was used to simulate the transient state tests in an incremental numerical procedure. The time steps applied in this procedure were taken as $\Delta t=0.2$ minutes. Equation [12] describes how the creep strain at the end of each time-step $i$ is determined based on the creep strain of the previous time-step $i-1$ and the creepstrain increment

$$
\varepsilon_{t, I+I I}^{i} \approx \varepsilon_{t, I+I I}^{i-1}+Z \cdot \mathrm{e}^{\frac{-Q}{R \cdot T}} \cdot \operatorname{coth}\left(\frac{\varepsilon_{t, I+I I}^{i-1}}{\varepsilon_{t 0}}\right) \cdot \Delta t
$$




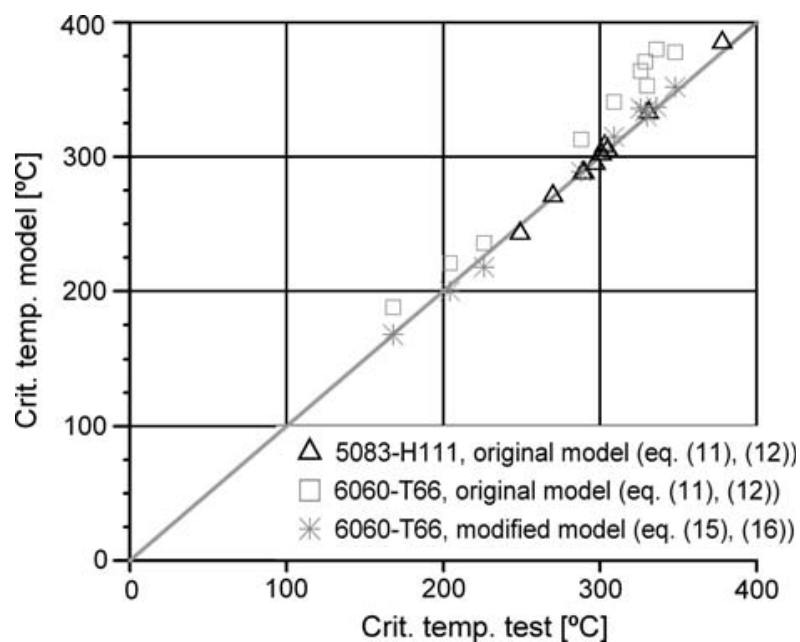

Fig. 16-Critical temperatures of the transient state tests compared with the model.

Table VI. Average and Standard Deviation of the Difference in Critical Temperature Between Transient State Tests and Model

\begin{tabular}{lcc}
\hline Alloy, type of model & Average & Standard Deviation \\
\hline $\begin{array}{c}5083-\mathrm{H} 111 \text {, original model } \\
\text { (Eqs. [11] and [12]) }\end{array}$ & $0.5^{\circ} \mathrm{C}$ & $3.7^{\circ} \mathrm{C}$ \\
$\begin{array}{c}\text { 6060-T66, original model } \\
\text { (Eqs. [11] and [12]) }\end{array}$ & $27.7^{\circ} \mathrm{C}$ & $10.6{ }^{\circ} \mathrm{C}$ \\
$\begin{array}{c}\text { 6060-T66, modified model } \\
(\text { Eqs. [15] and [16]) }\end{array}$ & $1.5{ }^{\circ} \mathrm{C}$ & $4.9{ }^{\circ} \mathrm{C}$ \\
\hline
\end{tabular}

Figure 16 gives a comparison between the critical temperature of the transient state tests and the simulation of these tests with the constitutive model (Eqs. [11] and [12]). The average value and standard deviation of the difference in critical temperature between the tests and the model are indicated in Table VI (data for "original model"). There is good agreement between tests and model in case of alloy 5083-H111 (indicated with black triangles in Figure 16). However, in the case of alloy 6060-T66, the simulations resulted in a too high critical temperature (indicated with gray squares).

The fact that the results of the model do not agree with the transient state tests for alloy 6060-T66 is attributed to the fact that the model only describes the primary and secondary stages of the creep-strain curve. Creep tests on alloy 6060-T66 showed that the tertiary creep stage started already at a low strain level (Figures 9 and 10(a)).

The creep strain as a function of time in the tertiary stage appeared to be independent of the gage length of the LVDT up to a strain of 0.02 . A linear relation was found between the creep-strain rate and the creep strain for strains up to approximately 0.02 in the tertiary creep stage of alloy 6060-T66 (Figure 10(b)). This relation appeared to be independent of the gage length of the LVDT. Besides, measurements on the thickness and width of the specimens loaded up to this strain (0.02) did not reveal a clear necking location. This indicates that although necking might have already initiated, the strain in tertiary creep stage can still be approximated as being homogeneous up to a strain of 0.02 . In this article, the tertiary creep stage is divided into two parts.

(1) A first part, from the start of the tertiary stage up to a strain of 0.02 . In this stage, although the strain rate increases in time, the strain can still be approximated as being homogeneous.

(2) A second part, from a strain of 0.02 up to rupture. In this stage, the strain is substantially inhomogeneous and a clear neck forms.

\section{MODIFICATION OF CONSTITUTIVE MODEL}

The creep-strain rate in the first part of the tertiary creep stage $\dot{\varepsilon}_{t, I I I}$ was found to be linear proportional to the creep strain $\varepsilon_{t, I}+I I+I I I$, where subscript $I I I$ indicates the first part of the tertiary creep stage, and $I+I I+I I I$ indicates the primary, secondary, and the first part of tertiary creep stages.

$$
\dot{\varepsilon}_{t, I I I}=C \cdot \dot{\varepsilon}_{t, I+I I+I I I}
$$

where $C$ is a constant. The creep strain at the start of the tertiary stage is denoted with symbol $\varepsilon_{\mathrm{lim}}$. For reasons of continuity, the creep-strain rate at the start of the tertiary stage should be equal to the secondary creep-strain rate. This allows for the elaboration of constant $C$ :

$$
C=\frac{\dot{\varepsilon}_{t, I+I I}}{\varepsilon_{\lim }}
$$

Incorporating this, the constitutive model including the first part of tertiary creep is described with Eq. [15], where $\varepsilon_{t, I}+I I+I I I$ is the creep strain of the primary, secondary, and the first part of the tertiary stages:

$$
\begin{gathered}
\varepsilon_{t, I+I I+I I I} \leq \varepsilon_{\lim }: \quad \varepsilon=\frac{\sigma}{E}+\int_{0}^{t} \dot{\varepsilon}_{t, I+I I} d t \\
\varepsilon_{t, I+I I+I I I}>\varepsilon_{\lim }: \quad \varepsilon=\frac{\sigma}{E}+\int_{0}^{t} \dot{\varepsilon}_{t, I+I I} \frac{\varepsilon_{t, I+I I+I I I}}{\varepsilon_{\lim }} d t
\end{gathered}
$$

The creep strain at the start of the tertiary stage $\varepsilon_{\text {lim }}$ (and the ratio between strain rate and strain $C$ ) varied between the creep tests. In many cases the tertiary stage started at the moment the temperature or stress was increased. The parameter is thus temperature and stress dependent. There were not enough test results to determine the relation between $\varepsilon_{\lim }$ and the temperature or stress. However, for transient state tests with increasing temperature, it appeared to be sufficiently accurate to use the average value of $\varepsilon_{\mathrm{lim}}$ of the creep tests (alloy 6060-T66: $\left.\varepsilon_{\mathrm{lim}}=0.0025\right)$. 
Similar to Eq. [2], Eq. [15] is an implicit equation. The transient state tests were simulated with the constitutive model according to Eq. [16], using a numerical procedure similar to that of Eq. [12]:

$$
\begin{aligned}
\varepsilon_{t, I+I I+I I I} \leq \varepsilon_{\lim }: \quad & \varepsilon_{t, I+I I}^{i} \approx \varepsilon_{t, I+I I}^{i-1} \\
& +Z \cdot \mathrm{e}^{\frac{-Q}{R \cdot T}} \cdot \operatorname{coth}\left(\frac{\varepsilon_{t, I+I I}^{i-1}}{\varepsilon_{t 0}}\right) \cdot \Delta t \quad \\
\varepsilon_{t, I+I I+I I I}>\varepsilon_{\lim }: \quad & \varepsilon_{t, I+I I}^{i} \approx \varepsilon_{t, I+I I}^{i-1} \\
& +Z \cdot e^{\frac{-Q}{R \cdot T}} \cdot \operatorname{coth}\left(\frac{\varepsilon_{t, I+I I}^{i-1}}{\varepsilon_{t 0}}\right) \cdot \frac{\varepsilon_{t, I+I I+I I I}^{i-1}}{\varepsilon_{\lim }} \cdot \Delta t
\end{aligned}
$$

The simulation results of some of the transient state tests carried out with the modified model (Eqs. [15] and [16]) are indicated with gray curves in Figures 11 and 12. The critical temperatures determined with the modified model (Eqs. [15] and [16]) agreed much better with the transient state tests carried out on alloy 6060-T66 than the original model (Figure 16 and Table VI). Based on this, the constitutive model developed is considered being appropriate for the determination of the constitutive properties of aluminum alloys exposed to fire.

\section{STRESS-STRAIN RELATIONSHIPS}

Figures 11, 12, and 16 show that the simulation of the strain of transient state tests with the constitutive model agree well with the measured strain in the test. The modified model (Eqs. [15] and [16]) is used to carry out transient state simulations with various constant stress levels, while keeping the heating rate constant. Each simulation results in a certain strain at a certain temperature. Varying the stress level gives stress-strain points in function of the temperature and the heating rate. Combining these points at the same temperature and heating rate leads to a stress-strain relation. This stress-strain relation is valid for the heating rate and exposure period considered. A similar procedure was followed in Reference 20 to determine the constitutive properties of fire-exposed steel. In case of steel, the stress-strain relationships were directly based on transient state tests, while in the current research on aluminum alloys they are based on simulations with the constitutive model.

Figure 17 gives the resulting stress-strain relationships for the aluminum alloys considered. The maximum temperature after a certain thermal exposure period is indicated in the graphs. The relationships are derived, and therefore valid, for a constant heating rate and a constant stress in time.

Figure 17 shows that the strength of fire-exposed aluminum not only depends on the temperature, but also on the exposure time. The same conclusion was drawn from the tests (Figures 11, 12, and 14). This is attributed to the fact that a longer exposure time results in more creep development. Especially in case of alloy 5083-H111, the stress-strain relationship is substantially curved and the proportional limit is very small compared to the 0.2 pet proof stress.

In the introduction, it was noted that transient state tests are considered as more appropriate for simulating fire conditions than steady-state tests. Comparing the transient state stress-strain curves with steady-state tensile tests used for the data in the design standard, ${ }^{[3]}$ it is found that the values for the 0.2 pct proof stress are different. In case of alloy 5083-H111, the data on the 0.2 pct proof stress in Reference 3 are 20 to 85 pct higher than the transient state values for the temperature range of $200{ }^{\circ} \mathrm{C}$ to $350{ }^{\circ} \mathrm{C}$. On the contrary, the data in
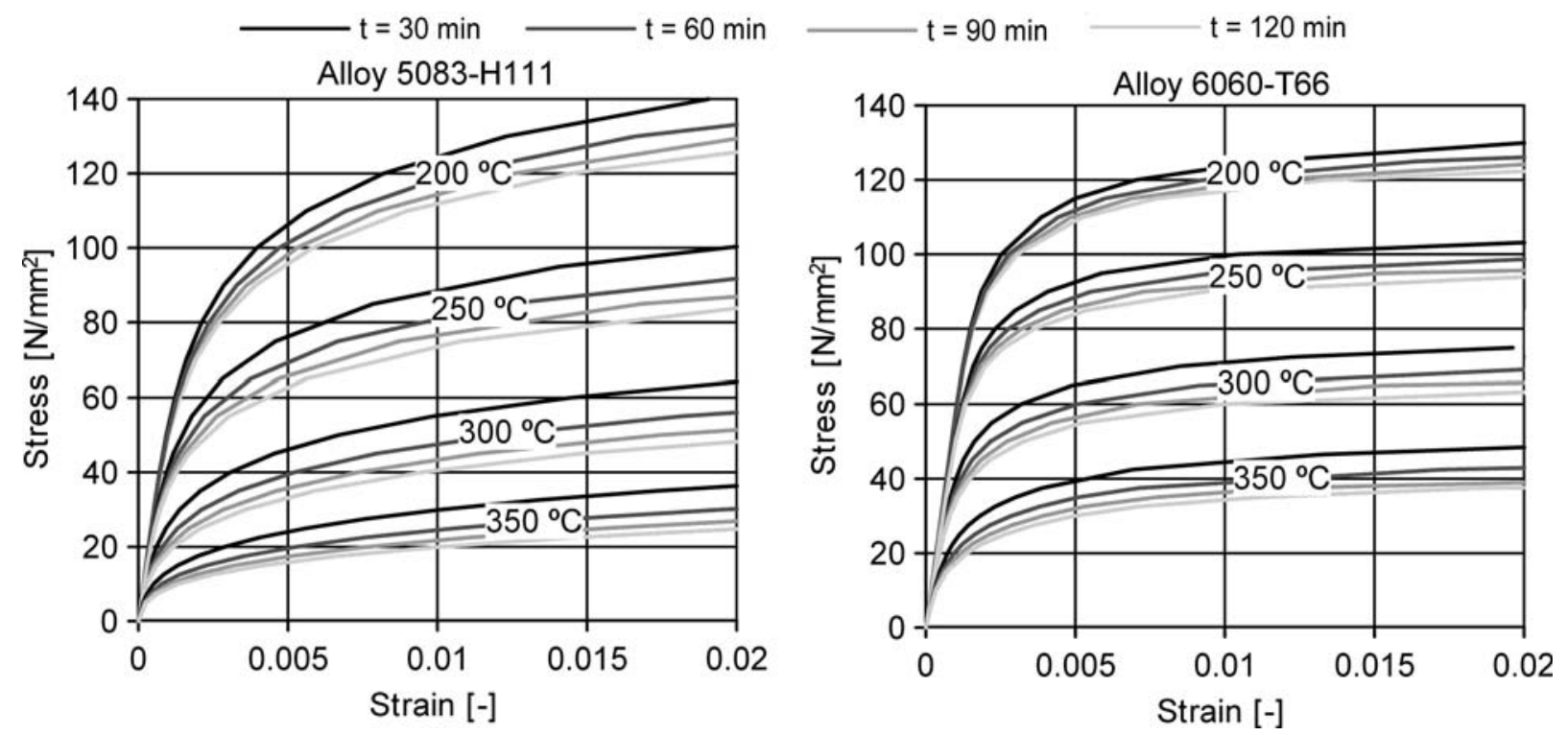

Fig. 17-Stress-strain relationships of fire-exposed aluminum alloys: (a) 5083-H111 and (b) 6060-T66. 
Reference 3 are 5 to 40 pct lower than the transient state values for alloy 6060 -T66 $\left(200{ }^{\circ} \mathrm{C}\right.$ to $\left.350{ }^{\circ} \mathrm{C}\right)$. Based on this, it is concluded that steady-state values for the 0.2 pct proof are inappropriate for fire design. The transient state stress-strain relationships according to Figure 17 can be incorporated in design standards for the design of fire-exposed aluminum structures.

\section{CONCLUSIONS}

An existing constitutive model for primary and secondary creep at elevated temperature, developed by Dorn and Harmathy, is verified with tests on two representative aluminum alloys, 5083-H111 and 6060T66. The existing model is suited to simulate the strain development of stressed samples of alloys in series $5 \mathrm{xxx}$ and temper $\mathrm{O}$ or $\mathrm{H} 111$ exposed to an increasing temperature, with heating rates ranging from $2.4{ }^{\circ} \mathrm{C} / \mathrm{min}$ to $11^{\circ} \mathrm{C} / \mathrm{min}$ and stress levels ranging from 20 to $100 \mathrm{~N} / \mathrm{mm}^{2}$. These conditions are considered as representative for fire exposure of insulated aluminum structures. The model appeared to be not suited to simulate the strain of precipitation hardened alloys in series $6 \mathrm{xxx}$ under similar conditions, which is attributed to the early development of tertiary creep.

The modified constitutive model, which includes the tertiary creep stage up to a strain of 2.5 pct, gives a much better agreement between simulations and tests on precipitation hardened alloys in series $6 \times x x$ than the existing model. The developed constitutive model is suited for insulated aluminum members exposed to temperature courses as present in fire.

In the first part of the tertiary creep stage (i.e., up to a strain of $2 \mathrm{pct}$ ), substantial necking with a concentration of the deformation was not yet detected. For engineering purposes the strain in this first part of the tertiary stage can be considered as being homogeneous. There exists a linear relation between the creep-strain rate and the creep strain for this first part of the tertiary creep stage.

Overaging and annealing influence the strength of precipitation hardened alloys at elevated temperature. However, in case of the heating rates that are relevant for fire design (listed previously), the influence of overaging and annealing on the strength of alloys in series 6xxx is so small that it can be neglected.

The stress-strain relationships of fire-exposed aluminum alloys not only depend on the maximum temperature, but also on the required fire resistance period. The value for the proportional limit is very low compared to the 0.2 pct proof stress for fire-exposed aluminum (especially for alloys in series $5 \mathrm{xxx}$ ).

The data on the 0.2 pct proof stress in Eurocode 9 Part 1-2, are based on steady-state tensile tests. Depending on the alloy, these values are unsafe or overly conservative for fire design. Instead, the strength data should be based on transient state tests.

\section{ACKNOWLEDGMENTS}

This research was conducted under Project No. MC1.02147 in the framework of the Strategic Research program of the Netherlands Institute for Metals Research in the Netherlands (www.nimr.nl).

\section{REFERENCES}

1. J. Maljaars, F. Soetens, and L. Twilt: 4th Int. Workshop Structures in Fire, P. Vila Real, J.M. Franssen, and N. Lopes, eds., Universitade de Aveiro, Aveiro, Portugal, 2006, vol. 1, pp. 75-88.

2. S. Lundberg: Hydro Aluminium R\&D Karmøy, Håvik, Norway, Mechanical Properties at Elevated Temperature for Aluminium Alloys, European Committee for Standardization Document CEN/TC 250/SC 9/PT Fire/N-27, unpublished research, 2003.

3. EN 1999-1-2: Design of Aluminium Structures-Part 1-2: General Rules-Structural Fire Design, European Committee for Standardization CEN/TC 250, Mar. 2007, pp. 18-21.

4. F.M Mazzolani: Aluminium Alloy Structures, 2 nd ed., Chapman \& Hall, London, 1995, pp. 41-63.

5. B. Faggiano, G. De Matteis, R. Landolfo, and M. Mazzolani: J. Civil Eng. Management, 2004, vol. 10 (2), pp. 183-90.

6. J.E. Dorn: J. Mech. Phys. Solids, 1954, vol. 3, pp. 85-116.

7. T.Z. Harmathy: J. Basic Eng., 1967, vol. 89, pp. 496-502.

8. J. Thor: Deformations and Critical Loads of Steel Beams under Fire Exposure Conditions, Doc. D 16, National Swedish Building Research, Stockholm, 1973, pp. 14-51.

9. J.G. Kaufman: Properties of Aluminium Alloys-Tensile, Creep, and Fatigue Data at High and Low Temperatures, 1st ed., ASM, Metals Park, OH, 1999, pp. 109-98.

10. C. Zener and H.H. Holloman: J. Appl. Phys., 1944, vol. 15, p. 22.

11. H.J. McQueen and J.J. Jonas: in Metal Forming, Interrelation Between Theory and Practice, A.L. Hoffmanner, ed., Plenum Publishing Corp, New York, NY, 1971, pp. 393-428.

12. H.R. Voorhees and J.W. Freeman: Report on the Elevated-Temperature Properties of Aluminium and Magnesium Alloys, ASTM STP No. 291, ASTM, Philadelphia, PA, 1960, pp. 109-12.

13. J.N. Webb: C.P. No. 1367, Aeronautical Research Council, London, UK, 1977, pp. 10-12.

14. A. Airod, R. Petrov, R. Colás, and Y. Houbaert: Mater. Forum, 2004, vol. 28, pp. 293-99.

15. T. Sheppard and A. Jackson: Mater. Sci. Technol., 1997, vol. 13, pp. 203-09.

16. M.A. Wells, I.V. Samarasekera, E.B. Hawbolt, J.K. Brimacombe, and R. Bolingbroke: in Light Metals Processing and Applications, C. Bickert, M. Bouchara, and G. Davies, eds., Canadian Institute of Mining, Metallurgy, and Petroleum, Quebec City, PQ, Canada, 1993, pp. 483-93.

17. W.M. Haaften: Constitutive Behaviour and Hot Tearing During Aluminium DC Casting, Delft University of Technology, Delft, Netherlands, 2002, pp. 20-29.

18. Y. Li and T.G. Langdon: Metall. Mater. Trans. A, 1998, vol. 29A, pp. 2523-31.

19. W.N. Findley, J.S. Lai, and K. Onaran: Creep and Relaxation of Nonlinear Viscoelastic Materials, Dover Publications, Inc, New York, NY, 1989, p. 5.

20. J. Witteveen and L. Twilt: Proc. IABSE, IABSE, Zurich, Switzerland, 1975, vol. 23, pp. 162-70. 